\title{
PENINGKATAN KEMAMPUAN PEMECAHAN MASALAH MATEMATIK SISWA KELAS 12 PADA MATERI DIMENSI TIGA MELALUI PENDEKATAN RECIPROCAL TEACHING
}

\author{
Deni Handayani ${ }^{1}$, Achmad Mirza ${ }^{2}$, Padillah Akbar ${ }^{3}$ \\ ${ }^{1,2}$ IKIP Siliwangi, Cimahi, Indonesia \\ handayanideni923@gmail.com
}

\begin{abstract}
This article was created to describe the research results of 24 students of MA Wasilatul Huda Cicalengka Bandung Regency with the aim of increasing indicators of mathematical problem solving ability, which in terms of each cycle, whether each cycle has increased or decreased, on which indicator questions do students find difficulties what kind of students can cause low field problem solving skills. The method used in this research is descriptive method with a qualitative approach. The research phase consisted of: planning, implementing classroom actions, observation and evaluation, and reflection. The results of the research conducted were obtained: 1) in cycle one the achievement of students' mathematical problem solving abilities was only $39.58 \%, 2)$ in cycle two the achievement of mathematical problem solving abilities increased to $61.98 \%, 3$ ) while in cycle three the average ability Mathematical problem solving increased to $79.34 \%$. Based on the results of the study, it can be concluded that classroom action research to measure the indicators of mathematical problem solving abilities has improved and achieved mastery in cycle three.
\end{abstract}

Keywords: Problem Solving ability, Reciprocal Teaching, polyhedron.

\begin{abstract}
Abstrak
Artikel ini dibuat untuk mendeskripsikan hasil penelitian MA Wasilatul Huda Cicalengka Kabupaten Bandung sebanyak 24 siswa dengan tujuan meningkatkan indikator kemampuan Pemecahan Masalah matematik, yang ditinjau dari setiap siklus, apakah dari setiap siklus tersebut mengalami peningkatan atau penurunan, pada soal indikator manakah siswa merasa kesulitan, kinerja siswa yang seperti apakah yang dapat meyebabkan rendahnya kemampuan Pemecahan Masalah dilapangan. Metode yang digunakan dalam penelitian ini yaitu metode deskriptif kualiatif. Adapun penelitian ini dilaksanakan untuk meningkatkan kemampuan pemecahan masalah siswa sehingga dapat meningkatkan prestasi siswa baik ditingkat lokal madrasah atau ditingkat Nasional dalam hal ini meningkatkan nilai UNBK, yang selama ini menurut data yang didapat dari Pusat Penilaian pendidikan dari KemenDikBUD rata-rata nilai UNBK pada tahun ajaran 2018-2019 dikabupaten Bandung terutama pada materi geometri 33,08 dan dimadrasah yang dijadikan subjek penelitian nilai rataratanya 32,7, jadi masih dibawah rata-rata ditingkat kabupaten, serta untuk meningkatkan kinerja pembelajaran dimadrasah.Tahap penelitian yang dilakukan terdiri dari: tahap perencanaan,tahap pelaksanaan tindakan kelas, obsevasi dan evaluasi, serta umpan balik. Hasil penelitian yang dilakukan diperoleh: 1) pada siklus satu pencapaian kemampuan Pemecahan Masalah matematik siswa hanya 39,58 \%,2) pada siklus dua pencapaian kemampuan Pemecahan Masalah matematik meningkat menjadi 61,98 \%, 3) sedangkan pada siklus tiga ratarata kemampuan Pemecahan Masalah matematik meningkat menjadi 79,34 \%. Berdasarkan hasil penelitian dapat disimpulkan bahwa penelitian tindakan kelas untuk mengukur indikator kemampuan Pemecahan Masalah matematik mengalami peningkatan yang lebih baik dan mencapai ketuntasan pada siklus tiga.
\end{abstract}

Kata kunci: Pemecahan Masalah matematik, Reciprocal Teaching, Dimensi tiga

\section{PENDAHULUAN}

Tujuan utama kegiatan belajar mengajar matematika di sekolah seperti ya adalah untuk melatih keterampilan kemampuan pemecahan masalah matematik siswa sehingga tidak heran jika di setiap standar kompetenti dan kompetensi dasar dijumpai penegasan diperlukannya kemampuan pemecahan masalah bagi siswa (Akbar, et., al., 2018), dengan begitu siswa dapat mengapilasikan keterampilan kemampuan pemecahan masalah pada kehidupan sehari hari atau pada dunia kerja (Aminah, Wijaya, \& Yuspriyati, 2018; Tommy Tanu Wijaya, Purnama, \& Tanuwijaya, 2020; Tommy Tanu Wijaya, 
Sukma, Purnama, \& Tanuwijaya, 2020). Fokus pada keterampilan memecahan masalah siswa sangatlah penting karena Kurangnya kemampuan tersebut telah dirasakan oleh siswa diantaranya siswa kurang memahami masalah baik dalam bentuk cerita maupun gambar, membuat model matematika dari suatu masalah atau gambar, mencari solusi dari model matematika tersebut (Bernard \& Setiawan, 2020; Bernard, et. al, 2020; Sari, 2020). akibat hal tesebut mengakibatkan prestasi belajar pun menjadi rendah (Hutajulu, Wijaya, \& Hidayat, 2019; Zulfah, Astuti, Surya, Marta, \& Wijaya, 2020). Hal ini sesuai dengan analisa pembelajaran yang peneliti laksanakan dengan memberikan sebuah masalah yang harus diselesaikan oleh 24 siswa kelas 12 MIPA.1 di MA Wasilatul Huda sebagai berikut salah satu contoh masalah dan solusi dari sebagian siswa di kelas 12 MIPA.1

Masalah : Diketahui sebuah balok memiliki perbandingan rusuk-rusuk $6: 3: 2$. Panjang diagonal rusuknya $21 \mathrm{~cm}$. Tentukanlah volume balok tersebut?

- Gambarlah sketsa dari tempat air tersebut, dilengkapi dengan unsur yang diketahui dan ditanyakan.

- Susun model matematika masalah dan tuliskan konsep yang termuat dalam model matematika tersebut.

- Susun strategi untuk menyelesaikan masalah dan selesaikan disertai dengan kosep atau rumus yang digunakan pada tiap langkah.

- Periksa kebenaran solusi yang diperoleh

solusi dari beberapa siswa tampak pada gambar dibawah Ini

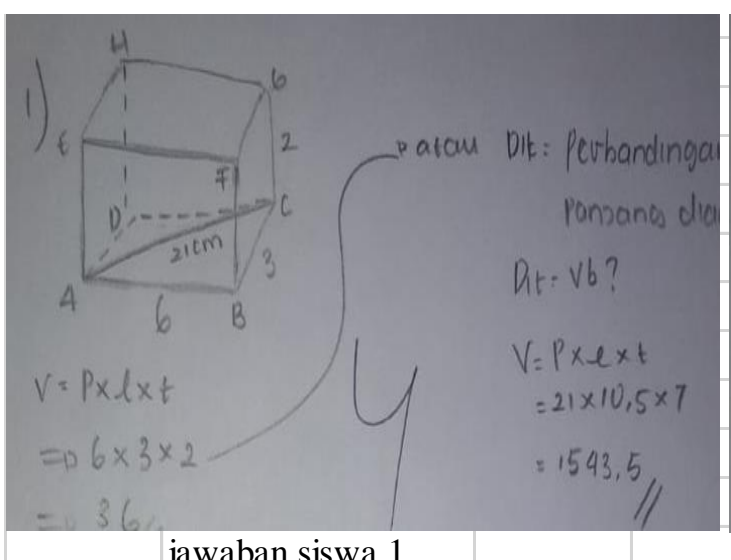

jawaban siswa 1

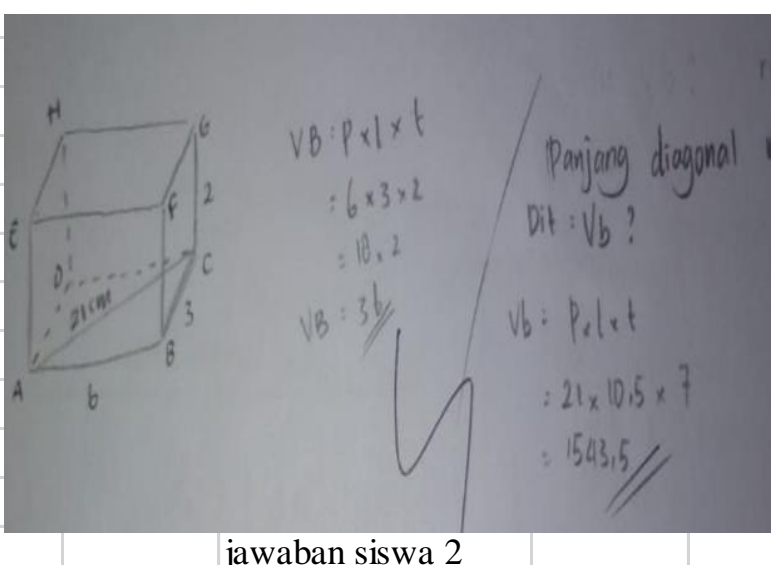

jawaban siswa 2

Gambar 1. Jawaban Siswa yang Kesulitan Membuat Model Matematika

Berdasarkan konteks masalah diatas itu sangat jelas bahwa siswa tersebut belum mempunyai keterampilan pemecahan masalah matematik, dari jawaban siswa tersebut sangat terlihat bahwa siswa tersebut belum bisa memahami perbedaan antara ukuran dan perbandingan, siswa belum bisa membuat model matematika dari suatu situasi masalah atau gambar, serta siswa belum bisa terbiasa dalam memeriksa kebenaran solusi , seperti yang diungkapakan Polya (Hendriana, Rohaeti, 
Soemarmo, 2017) Langkah-langkah dalam pemecahan masalah yaitu : a) Memahami konteks masalah ,b) Mengaitkan unsur yang diketahui dan ditanyakan dalam soal dan merumuskannya dalam bentuk model matematikanya, c) Memilih strategi penyelesaian, mengelaborasi, dan menyelesaikan model matematika dan Menginterpretasikan hasil terhadap masalah semula dan memeriksa kembali kebenaran solusi dari proses penyelesaian. Keterampilan pemecahan masalah merupakan tujuan umum pengajaran matematika, hal ini mengandung pengertian bahwa matematika dapat membantu dalam memecahkan persoalan baik dalam pelajaran lain maupun dalam kehidupan sehari-hari (Linda, et. al, 2020, Wiliawanto, et, al, 2019; pirmanto, et. al, 2020). Oleh karenanya kemampuan pemecahan masalah ini menjadi tujuan umum pembelajaran matematika. Menurut Branca (dalam Hendriana, Soemarmo, 2014) mengemukakan bahwa pemecahan masalah matematik mempunyai dua makna yaitu sebagai suatu pendekatan pembelajaran, sebagai kegiatan atau proses dalam melakukan doing math. Pemecahan masalah matematik sebagai suatu pendekatan dalam pembelajaran yng melukiskan pembelajaran yang diawali dengan penyajian masalah kontekstual yang kemudian melalui penalaran induktif siswa menemukan kembali konsep yang dipelajari dan kemampuan matematik lainnya, artinya bahwa keterampilan kemampuan masalah ini sangat penting untuk dikembangkan pada diri siswa, karena merupakan salah satu tujuan dari pembelajaran matematika.

Berdasarkan penelitian yang telah dilakukan peneliti sebelumnya, banyak alternatif yang dapat digunakan untuk meningkatkan kemampuan matematis siswa baik menggunakan pendekatan dan model pembelajaran (Dewi, Wijaya, Budianti, \& Rohaeti, 2018; Lin, Zhou, Wang, \& Wijaya, 2020), atau menggunakan software teknologi pada kegiatan belajar mengajar (Suan, Ying, \& Wijaya, 2020; T.T. Wijaya, Ying, \& Purnama, 2020; Tommy Tanu Wijaya, Sukma, et al., 2020; Tommy Tanu Wijaya, Ying, Chotimah, \& Bernard, 2020). Adapun langkah alternatif yang tepat dilakukan untuk mengatasi masalah tentang rendahnya kemampuan Matematik siswa di Madrasah Aliyah Wasilatul Huda yaitu dengan cara mengembangkan keterampilan Kemampuan pemecahan masalah Matematik dengan menggunakan Pendekatan pembelajaran yang tepat dalam hal ini penulis menggunakan pendekatan Reciprocal Teaching, karena pembelajaran dengan pendekatan ini, siswa di biasakan untuk memahami masalah sendiri, membuat pertanyaan dari suatu masalah , mencatat hal hal yang belum dipahami, membuat pemodelan dari suatu masalah matematik, menyelesaikannya, bisa menjelaskan kepada teman sekelasnya dan membagi pemahamannya dengan teman sekelasnya, jadi pendekatan reciprocal teaching diartikan bahwa pembelajaran terbalik (Reciprocal Teaching) artinya suatu pendekatan pembelajaran yang dirancang untuk memberikan manfaat agar tujuan pembelajaran tercapai dan memberikan keterampilan pada siswa dalam memahami apa yang telah dibaca didasarkan pada pengajuan pertanyaan, senada dengan yang diungkapkan oleh Palinscar,Brown ( dalam Evendi,2001:5 ) bahwa kegiatan-kegiatan dalam model pembelajaran tebalik (Reciprocal ) langkah lngkahnya sebagai berikut: a). Menyusun pertanyaan, b). Membuat ringkasan ( ikhtisar ), c). Membuat prediksi dan d). Mengklasifikasi atau mencatat hal-hal yang kurang jelas dari bacaan. Kemudian Menurut Suyatno (2009 : 64) langkah-langkah pelaksanaan reciprocal teaching antara lain : a) 
Membagikan bacaan hari ini, b) Menjelaskan bahwa guru berperan sebagai guru pada bacaan pertama, c) Meminta siswa membaca bacaan pada bagian yang ditetapkan, d) Setelah membaca, siswa disuruh melakukan pemodelan, e) Meminta siswa memberikan komentar terhadap pembelajaran guru, f) Siswa lain membaca dengan tidak bersuara bagian materi bacaan yang lain, g) Memilih salah satu siswa yang berperan sebagai guru, h) Membimbing siswa yang berperan sebagai guru, i) Mengurangi bimbingan siswa yang menjadi guru secara periodik. Pengajaran terbalik terutama dikembangkan untuk membantu guru menggunakan dialog-dialog belajar yang bersifat kerjasama untuk mengajarkan pemahaman bacaan secara mandiri (Trianto, 2007 : 96). Melalui pengajaran terbalik, siswa diajarkan empat strategi pemahaman pengaturan diri yaitu merangkum, pengajuan pertanyaan, komunikasi dan prediksi (Bernard \& Sunaryo, 2020).

Sebagai mana kenyataan dilapangan sebagai bukti nyata penelitian terdahulu bahwa pendekatan reciprocal teaching dapat meningkatkan keterampilan kemampuan matematika yaitu Juhaeri $\mathrm{M}$. (2014). Dalam penelitiannya yang berjudul "Peningkatan Kemampuan Berpikir Kritis, Berpikir Kreatif Matematis, Dan Self-Concept Siswa Smp Melalui Metode Reciprocal Teaching" dalam simpulannya mengatakan bahwa pendekatan reciprocal teaching dapat membantu siswa dalam meningkatakan kemampuan berpikir kritis dan Kreatif matematis, senada dengan penelitian Ari Hestaliana. R, 2015 yang berjudul "meningkatkan kemampuan pemecahan masalah, komunikasi, dan self-regulation matematis melalui penerapan model pembelajaran reciprocal teaching berbasis saintifik pada siswa smp" dalam simpulannya mengatakan bahwa Peningkatan kemampuan pemecahan masalah matematis siswa yang memperoleh pembelajaran dengan model reciprocal teaching berbasis saintifik lebih baik daripada siswa yang memperoleh pembelajaran dengan pendekatan saintifik. Oleh sebab itu penulis bermaksud untuk menggunakan pendekatan pembelajaran reciprocal teaching dalam meningkatkan kemampuan pemecahan masalah matematik pada siswa kelas 12 MIPA.1 di Madrasah Aliyah Wasilatul Huda Cicalengka.

\section{METODE}

Metode Penelitian pada penelitian ini adalah penelitian tindakan kelas dengan pendekatan kualitatif, penelitian ini mendeskrifsikan tentang penelitian tindakan kelas dari siklus satu hingga siklus tiga dengan tahapan setiap siklusnya : perencanaan, pelaksanaan , pengamatan dan refleksi, serta hasil refeksi dijadikan evaluasi untuk perencanaan pada sikus berikutnya seperti yang diungkapkan Kemmis dan Mc Taggart dalam Sukayati (2008:17) yang tampak pada skema dibawah ini : 


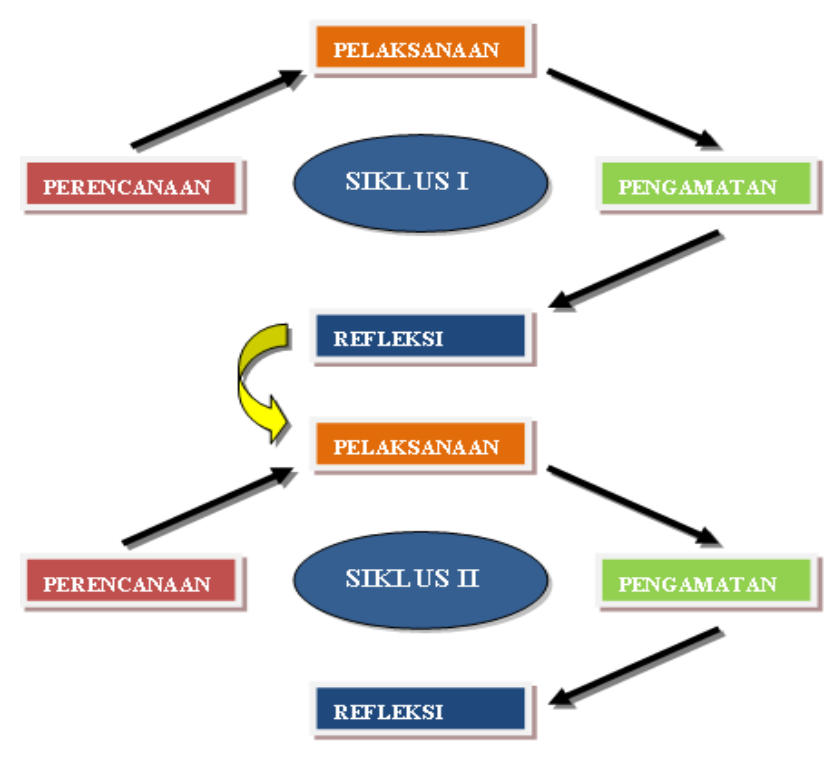

Gambar. 2 Alur Pelaksanaan PTK Model Kemmis dan Taggart

Dalam meningkatkan indikator kemampuan Pemecahan Masalah matematik metode kuantitatif berkonsentrasi pada apa yang ada, atau karena metode hanya menawarkan bantuan terbatas ketika melihat ke arah masa depan Easterby Smith (Susila, 2015) Oleh karena itu, metode kualitatif lebih memungkinkan memberikan sumbangsih terbesar terhadap munculnya teori baru melalui pemahaman proses perilaku dan pengalaman individu. Penelitian ini dilaksanakan mulai 25 Agustus 2020 sampai 19 September 2020 pada semester ganjil tahun akademik 2020/2021 di MA Wasilatul Huda Cicalengka Kabupaten Bandung dengan subjek penelitian adalah siswa kelas 12 MIPA.1 dengan jumlah siswa 24 orang terdiri dari 20 orang perempuan dan 4 orang siswa laki-laki, walaupun dalam keadaan wabah covid -19, karena di MA Wasilatul Huda Cicalengka terintegrasi dengan pesantren sehingga dengan menggunakan protokoler kesehatan yang ketat kepada siswa maupun guru, alhamdulillah disekolah kami masih bisa melaksanakan kegiatan belajar mengajar Tatap muka atau luar jaringan, sehingga penulis bisa melaksanakan penelitian tindakan kelas , Intrumen dalam penelitian ini adalah peneliti sendiri, dimana peneliti sebagai perencana kegiatan, pelaksana kegiatan , pengumpul data, penganalisis dan penapsir data.

Selain itu instrumen yang lainya adalah sejumlah soal tes setiap siklusnya kemampuan Pemecahan Masalah Matematik. Penelitian tindakan kelas ini direncanakan terdiri dari 3 (tiga) siklus yang didasarkan pada silabus pengajaran guru matematika . Tiap siklus dilaksanakan sesuai dengan perubahan yang ingin dicapai. Sebelum dilaksanakan tindakan, terlebih dahulu diberikan tes awal dengan maksud untuk mengetahui kemampuan awal siswa dan berkaitan dengan materi yang akan diajarkan yaitu Dimensi Tiga . Setiap siklus dalam penelitian ini meliputi prosedur berikut: (1) perencanaan; (2) pelaksanaan tindakan; (3) Observasi dan evaluasi; dan (4) umpan balik.

\section{HASIL}

Indikator kemampuan masalah matematik dalam penelitian ini adalah seperti yang diungkapkan 
Langkah-langkah pemecahan masalah menurut Polya (Hendriana, Rohaeti, Soemarmo, 2017). 1).Memahami konteks masalah 2). Mengidentifikasi unsur yang diketahui dan ditanyakan dan merumuskan masalh dalam bentuk model matematika masalah. 3). Memilih strategi penyelesaian yang tepat, mengelaborasi, dan menyelesaikan model matematika. 4). Menginterpretasikan hasil terhadap masalah semula dan memeriksa kembali kebenaran solusi. Dengan menggunakan kaidah penskoran dari Soemarmo dalam (Hendriana, Rohaeti, Soemarmo, Yuliani, 2019) seperti yang ditampilkan pada tabel 1 .

Tabel 1.

Kaidah penskoran indikator pemecahan masalah matematika

\begin{tabular}{|l|l|l|}
\hline No & Indikator pemecahan maslah & Skor \\
\hline 1 & Memahami masalah / menggambar masalah & $0-2$ \\
\hline 2 & $\begin{array}{l}\text { Mengaitkan unsur yang diketahui dan ditanyakan dan merumuskannya dalam } \\
\text { bentuk model matematika masalah }\end{array}$ & $0-3$ \\
\hline 3 & $\begin{array}{l}\text { Memilih strategi penyelesaian, mengelaborasi, dan menyelesaikan model } \\
\text { matematika }\end{array}$ & $0-3$ \\
\hline 4 & $\begin{array}{l}\text { Menginterpretasikan hasil terhadap masalah semula dan memeriksa kembali } \\
\text { kebenaran solusi. }\end{array}$ & $0-2$ \\
\hline & Total Skor & $0-10$ \\
\hline
\end{tabular}

Pada tabel 2 dapat dilihat Hasil presentasi rata-rata peningkatan indikator kemampuan Pemecahan Masalah matematik dari siklus satu hingga siklus tiga.

Tabel 2.

Hasil Tes Indikator Kemampuan pemecahan masalah Matematik Siklus satu Sampai Tiga

\begin{tabular}{|l|l|l|l|l|l|}
\hline \multirow{2}{*}{ Siklus } & \multicolumn{5}{|c|}{ Tes Indikator Kemampuan Pemecahan Masalah Matematik dalam (\%) } \\
\cline { 2 - 6 } & $\mathbf{1}$ & $\mathbf{2}$ & $\mathbf{3}$ & $\mathbf{4}$ & rata rata (\%) \\
\hline Siklus I & 87,50 & 34,72 & 19,44 & 16,67 & 39,58 \\
\hline Siklus II & 95,83 & 63,89 & 48,61 & 39,58 & 61,98 \\
\hline Siklus III & 100,00 & 81,94 & 75,00 & 60,42 & 79,34 \\
\hline
\end{tabular}

Pada siklus satu tampak bahwa pada indikator kemampuan Pemecahan Masalah matematik pada indikator Nomor 1 Memahami masalah / menggambar masalah nilai presentasi siswa sudah mencapai $87,50 \%$, pada indikator Nomor 2 Mengaitkan unsur yang diketahui dan ditanyakan dan merumuskannya dalam bentuk model matematika masalah $34,72 \%$ dan pada indikator nomor 3 Memilih strategi penyelesaian, mengelaborasi, dan menyelesaikan model matematika mencapai 19,44 \% dan pada indikator nomor 4 Menginterpretasikan hasil terhadap masalah semula dan memeriksa kembali kebenaran solusi mencapai 16,67 \% dengan demikian kemampuan siswa masih cukup rendah karena sekor prolehan rata-rata secara keseluruhan hanya mencapai 39,58 \% 
Berdasarkan pengamatan yang dilakukan peneliti, hasil penelitian pada siklus II pelaksanaan sekenario pembelajaran oleh guru telah mencapai indikator kemampuan Pemecahan Masalah matematis dan sekenario kemampuan Pemecahan Masalah matematis telah mencapai 61,98 \% dengan nilai perolehan ini dapat disimpulkan bahwa penelitian ini belum tercapai karena belum melampaui KKM yang ditentukan oleh madrasah, karena untuk kemampuan pemecahan masalah ini diinterintegrasikan dalam satu soal. Pada siklus dua tampak bahwa pada indikator Nomor 1 Memahami masalah / menggambar masalah nilai presentasi siswa sudah mencapai 95,83\%, pada indikator Nomor 2 Mengaitkan unsur yang diketahui dan ditanyakan dan merumuskannya dalam bentuk model matematika masalah 63,89\% hal ini menunjukan bahwa pada indikator ini masih perlu ditingkatakan untuk npembelajaranya pada siklus selanjutnya, pada indikator nomor 3 Memilih strategi penyelesaian, mengelaborasi, dan menyelesaikan model matematika mencapai 48,61\% dan pada indikator nomor 4 Menginterpretasikan hasil terhadap masalah semula dan memeriksa kembali kebenaran solusi mencapai $39,58 \%$.

Pada siklus III pembelajaran dilakukan selama 2 kali setelah selsai melakukan pertemuan kedua pada siklus tiga, maka diadakan tes Siklus tiga, untuk mengetahui apakah siklus tiga peningkatanya lebih baik daripada siklus dua atau sebaliknya. Dari pengamatan yang dilakukan peneliti, hasil penelitian pada siklus dua dapat dari dua segi yaitu: pelaksanaan sekenario pembelajaran oleh guru telah mencapai indikator kemampuan Pemecahan Masalah matematis dan sekenario kemampuan Pemecahan Masalah matematis telah mencapai ketuntasan dengan nilai perolehan diatas $65 \%$ yakni dengan perolehan rata rata tiap indikator 79,34\% maka dapat disimpulkan bahwa penelitian ini sudah tercapai.

\section{Presentasi Hasil Tes Kesulitan Indikator Kemampuan Pemecahan Masalah matematik Tiap Siklus}

Pada tabel 3 dapat dilihat Hasil presentasi rata-rata kesalahan siswa dalam menyelsaikan soal indikator kemampuan Pemecahan Masalah pada tiap siklus.

\section{Tabel 3.}

Kesalahan Tes soal Indikator Kemampuan pemecahan masalah Matematik Tiap Siklus

\begin{tabular}{|l|c|c|c|c|}
\hline Siklus & \multicolumn{4}{|l|}{$\begin{array}{l}\text { Tes Indikator Kemampuan Pemecahan Masalah } \\
\text { matematik dalam (\%) }\end{array}$} \\
\hline & 1 & 2 & 3 & 4 \\
\hline Siklus I & 12,50 & 65,28 & 80,56 & 83,33 \\
\hline Siklus II & 4,17 & 36,11 & 51,39 & 60,42 \\
\hline Siklus III & 0,00 & 18,06 & 25,00 & 39,58 \\
\hline & & & & \\
\hline
\end{tabular}

Pada siklus I siswa mayoritas medapatkan nilai yang lebih kecil karena pada pertemuan awal guru pembelajaranya belum optimal baik dari segi pembelajaran, pendekatan seta metode pembelajaran yang diterapkan sehingga siswa belum bisa beradaptasi dengan pembelajaran yang dihadapkan pada 
indikator Nomor 1 Memahami masalah/menggambar masalah nilai presentasi kesalahan siswa mencapai 12,50 \%, pada indikator Nomor 2 Mengaitkan unsur yang diketahui dan ditanyakan dan merumuskannya dalam bentuk model matematika masalah mendapat presentasi kesalahan sebesar $65,28 \%$, pada indikator nomor 3 Memilih strategi penyelesaian, mengelaborasi, dan menyelesaikan model matematika mendapat presentasi kesalahan sebesar 80,56 \% dan pada indikator nomor 4 Menginterpretasikan hasil terhadap masalah semula dan memeriksa kembali kebenaran solusi mencapai 83,33\%, Pada Siklus ini ada beberapa siswa belum bisa menjawab soal tidak sempurna atau bernilai nol terutam pada indikator nomor 2 dan nomor 3 karena ada kesalahan pada indikator 1 dan 2 dengan demikian kemampuan siswa masih cukup rendah. Adapun beberapa sampel jawaban siswa pada siklus 1 pada indikator dengan kesalahan terendah dapat dilihat pada gambar 2.
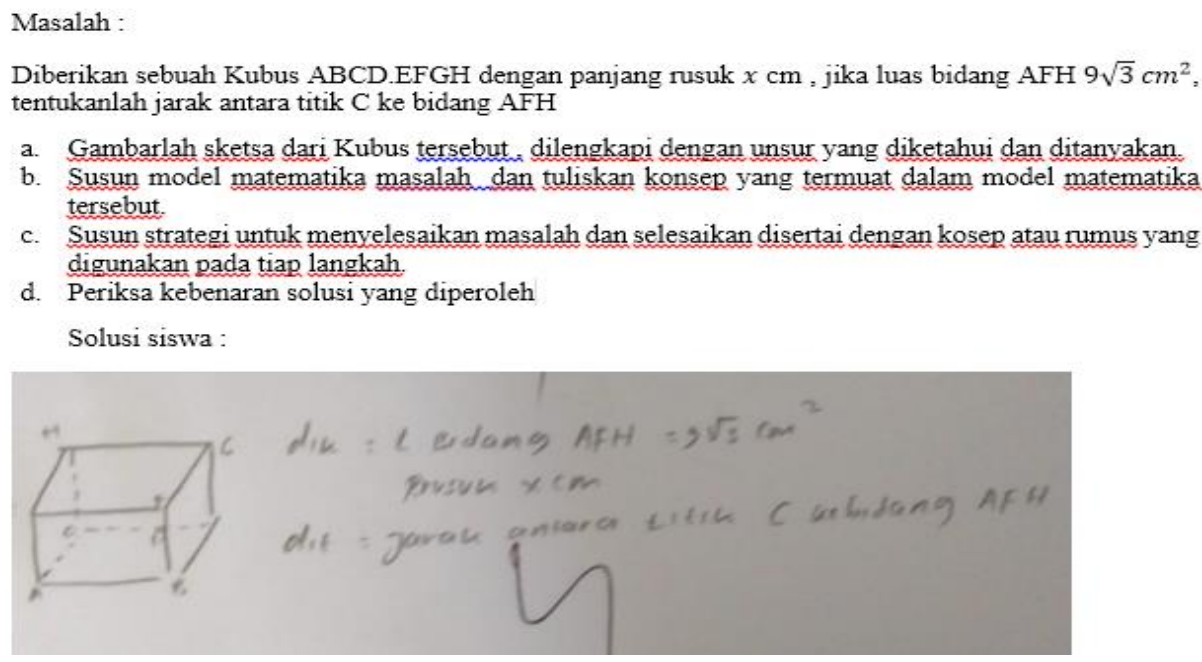

Gambar 2. Kesalahan pada siklus 1

Pada gambar tampak bahwa kemampuan siswa pada indikator membuat gambar dari situasi masalah yang disajikan, membuat model matematika, serta solusi dari masalah yang disajikan masih sangat lemah, hal tersebut pada tahap siklus 1 karena mereka belum terbiasa jika sebuah masalah, harus disajikan dengan membuat model matematika terlebih dahulu, apalagi harus mencari solusinya.

Pada siklus dua terdapat kesalahan siswa atau merasa kesulitan dengan memperoleh skor rata-rata perolehan pada indikator Nomor 1 Memahami masalah/menggambar masalah nilai presentasi kesalahan siswa mencapai 4,17 \%, pada indikator Nomor 2 Mengaitkan unsur yang diketahui dan ditanyakan dan merumuskannya dalam bentuk model matematika masalah mendapat presentasi kesalahan sebesar $36,11 \%$, pada indikator nomor 3 Memilih strategi penyelesaian, mengelaborasi, dan menyelesaikan model matematika mendapat presentasi kesalahan sebesar 51,39\% dan pada indikator nomor 4 Menginterpretasikan hasil terhadap masalah semula dan memeriksa kembali kebenaran solusi mencapai $60,42 \%$. kesulitan pada masalah dibawah ini adalah terletak pada indikator membuat model matematika, tetapi kerangka berpikir pemecahan masalah matematik sudah mulai terlihat pada siswa, pada gambar 3 terdapat sampel jawaban salah satu siswa mengenai 
kesulitan dalam jawaban pada materi lingkaran jarak antara dua titik pada bangun ruang sisi datar.

Masalah :

Seekor semut merayap di kubus $\mathrm{ABCD}$.EFGH dengan rusuk $8 \mathrm{~m}$ dimana $\mathrm{ABCD}$ sbg bidang dasar. Ia merayap mulai titik M yg terletak $2 \mathrm{~m}$ di atas $\mathrm{A}$ dan berhenti di titik $\mathrm{N}$ yg terletak $2 \mathrm{~m}$ di bawah $\mathrm{G}$.

Tentukan lintasan terpendek yg ditempuh semut tersebut !

a. Gambarkan situasi diatas dalam sebuah gambar

b. Identifikasi unsur yang diketahui dan ditanyakan

c. Susun model matematika masalah (unsur yang ditanyakan). Tulis konsep yang termuat dalam model tersebut.

Solusi Siswa :

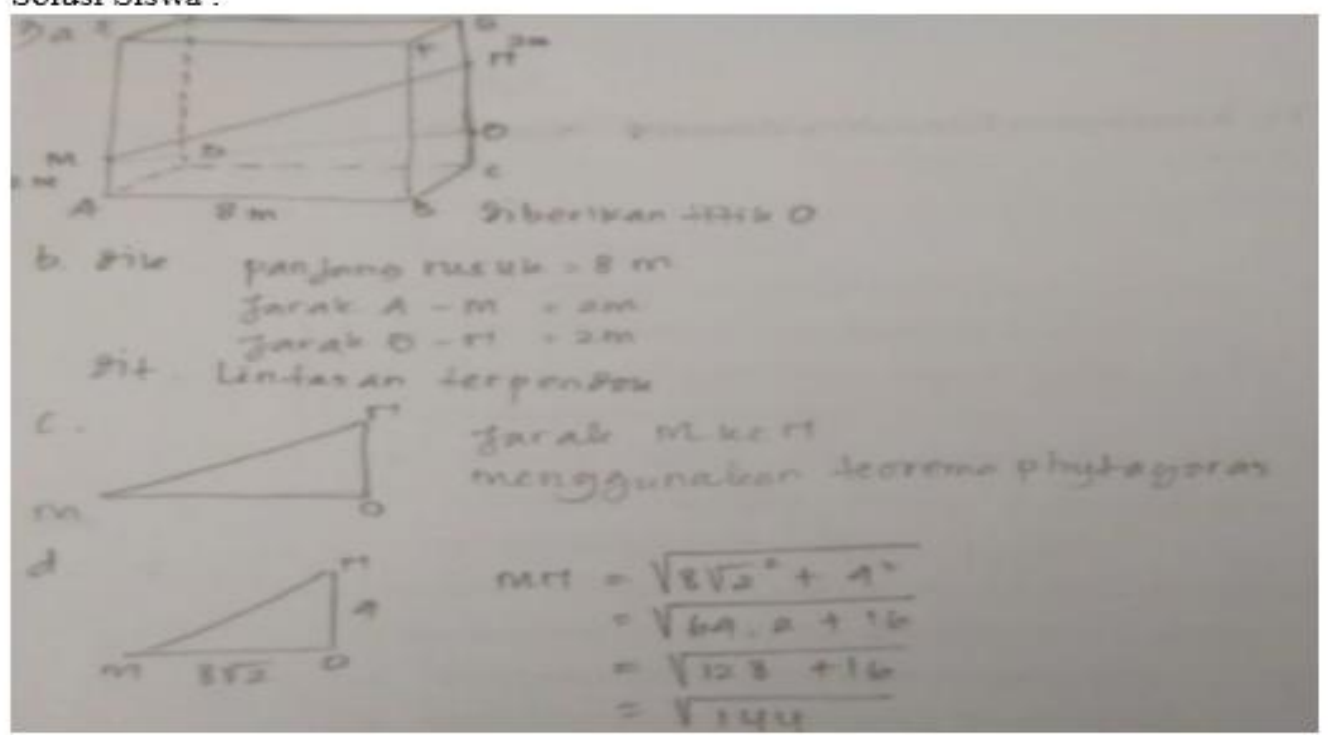

Gambar 3. Kesalahan pada Siklus 2

Pada soal untuk siklus dua dengan melihat jawaban siswa tersebut sudah terlihat keterampilan berpikir pemecahan masalah matematika sudah mulai ada peningkatan dibandingkan dengan yang terjadi pada siklus I, tetapi siswa tersebut belum menjawab solusi dengan tepat karena kesulitan membuat model matematika dari sebuah situasi, karena semut tidak akan bisa melewati garis MO yang ditunjukan oleh siswa tersebut.

Pada siklus tiga siswa merasa kesulitan dengan cara melihat hasil tes akhir dapat dilihat pada indikator Nomor 1 Memahami masalah/menggambar masalah nilai presentasi kesalahan siswa mencapai $0 \%$, pada indikator Nomor 2 Mengaitkan unsur yang diketahui dan ditanyakan dan merumuskannya dalam bentuk model matematika masalah mendapat presentasi kesalahan sebesar 18,06 \%, pada indikator nomor 3 Memilih strategi penyelesaian, mengelaborasi, dan menyelesaikan model matematika mendapat presentasi kesalahan sebesar $25 \%$ dan pada indikator nomor 4 Menginterpretasikan hasil terhadap masalah semula dan memeriksa kembali kebenaran solusi mencapai 39,58 \%. Dengan demikian kemampuan siswa sudah mengalami peningkatan yang lebih baik. Karena secara keseluruhan sudah cukup baik melebihi batas KKM maka penelitian sudah cukup pada siklus tiga. 


\section{Masalah :}

Diketahui kubus ABCD.EFGH dengan luas permukaannya adalah $216 \mathrm{~cm}^{2}$. Jarak diagonal ruang $\mathrm{BH}$ dan diagonal sisi $\mathrm{AC}$ adalah...

a. Gambarkan situasi diatas dalam sebuah gambar

b. Identifikasi unsur yang diketahui dan ditanyakan

c. Susun model matematika masalah (unsur yang ditanyakan). Tulis konsep yang termual dalam model tersebut.

d. Rancang strategi untuk menyelesaikan model tadi, dan kemudian selesaikan. Sertakan konsep yang digunakan pada tiap langkah penyelesaian.

Solusi siswa :

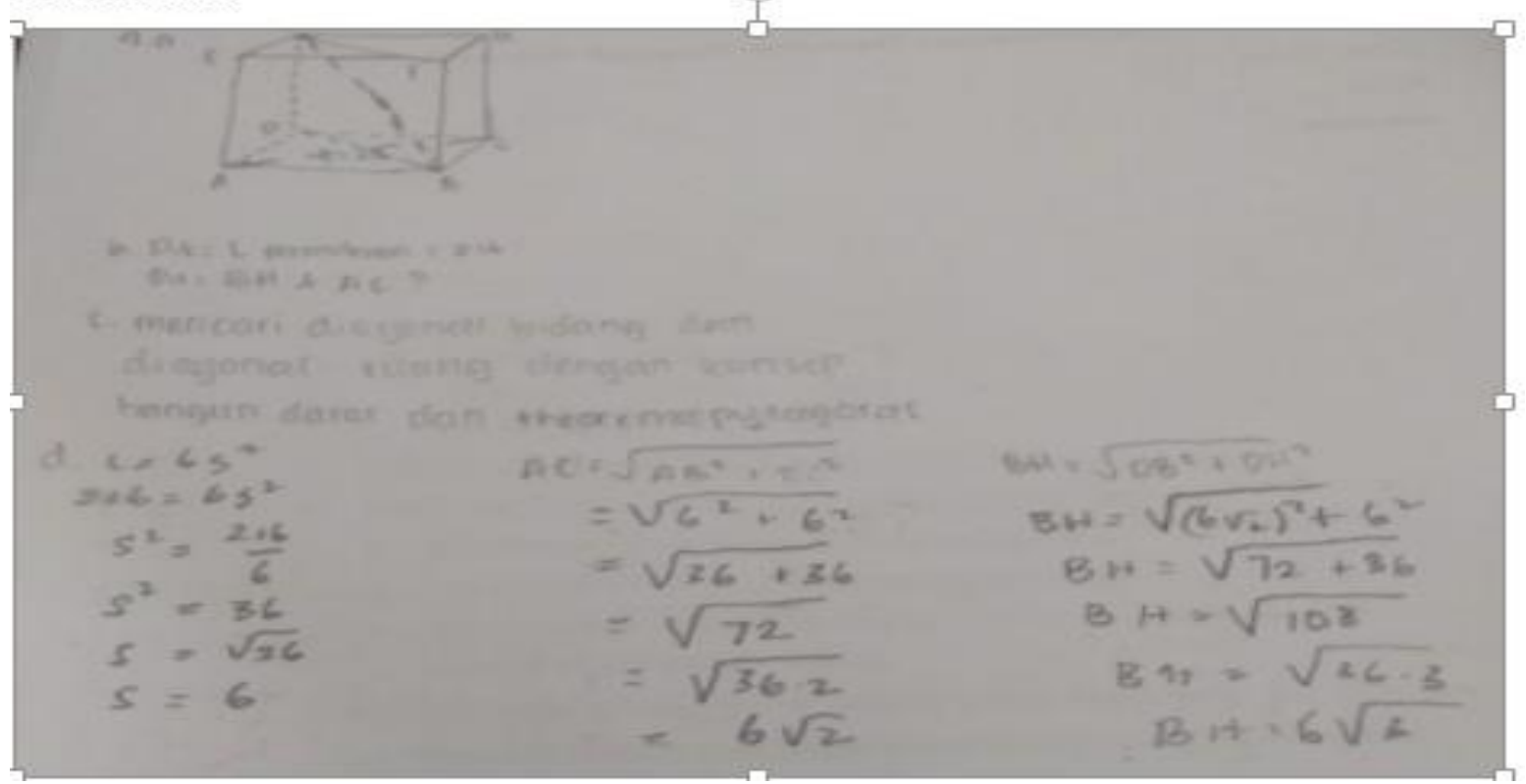

Gambar 4. Kesulitan Siswa Pada Siklus III

Pada gambar 4 Adapun salah satu sampel soal hasil pengerjaan siswa merasa kesulitan untuk menentukan jarak antara dua garis, siswa kesulitan menentukan proyeksi garis yang menjadi jarak antara garis $\mathrm{BH}$ dan garis $\mathrm{AC}$, tetapi terlihat bahwa kemampuan membuat gambar dari situasi masalah, pemodelan matematika serta langkah langkah untuk mendapatkan solusi dari masalah diatas sudah tepat. Sehingga secara umum untuk pencapaian idikator telah meningkat walupun peningkatanya hanya beberapa persen dari KKM yang telah ditentukan dengan peningkatan diatas 65 $\%$ hal lain bahwa kesulitan siswa pada siklus 3 dapat dikategorikan lebih baik.

\section{Kinerja Siswa Pada Setiap Siklus}

Hasil observasi terhadap siswa pada siklus satu menunjukan hal hal sebagai berikut: Siswa terlihat asing dengan pendekatan Reciprocal Teaching yang diterapkan didalam kelas, karena siswa terbiasa menerima penjelasan dari Guru, tanpa berpikir mereka untuk memahami masalah terlebih dahulu , menjelaskan kepada teman sekelompoknya kemudian menjelaskan kepada semua teman sekelasnya, tetapi untuk kegiatan belajar mengajar pada siklus Kedua dan ketiga mereka sudah terbiasa dan menyesuaikan dengan pendekatan Reciprocal teaching yang diterapkan oleh guru (Penulis), sebagai gambaran berikut dipaparkan garis besar langkah pembelajaran pendekatan 
Reciprocal teaching yang dilaksanakan pada PTK ini diantaranya adalah : guru meyampaikan tujuan pembelajaran yang dilaksanakan, memberikan stimulus berupa masalah yang ditampilkan dengan menggunakan aplikasi geogebra dan menyampaikan materi prasyarat, Siswa mengerjakan Lembar kerja Siswa, Diskusi Kelompok (salah seorang siswa bertindak sebagai guru), Diskusi antar kelompok, Diskusi Kelas ( salah seorang siswa bertindak sebagai guru di depan ) kemudian diakhiri oleh penguatan materi dari guru serta mengerjakan soal pengembangan. Demikian sekilas langkahlangkah kegiatan belajar mengajar yang dilaksanakan pada penelitian tindakan kelas ini, seperti yang tampak pada gambar 5 dibawah ini.

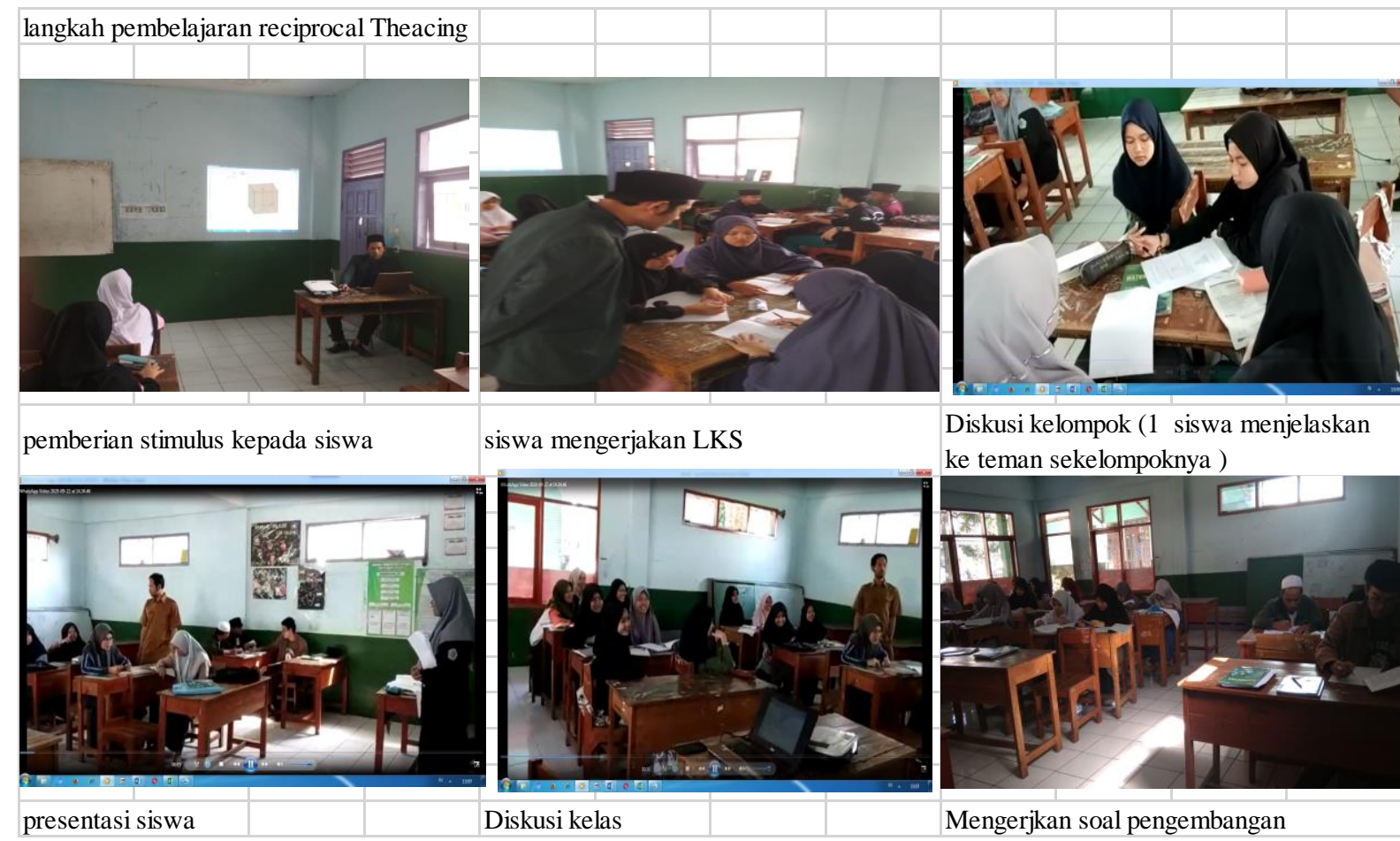

Gambar 5. Langkah pembelajaran reciprocal teaching

Penelitian ini dilakukan pada salah satu sekolah MA Wasilatul Huda Cicalengka Kabupaten Bandung dengan tujuan meningkatkan indikator kemampuan Pemecahan Masalah matematik, yang ditinjau dari setiap siklus, apakah dari setiap siklus tersebut mengalami peningkatan atau penurunan dengan menggunakan pendekatan Reciprocal Teaching, melihat pada soal dengan indikator manakah siswa merasa kesulitan serta kinerja siswa yang seperti apakah yang dapat mempengaruhi menurunya prestasi siswa serta rendahya kemampuan Pemecahan Masalah matematik dilapangan. Setelah ditinjau dilapangan bahwa kemampuan Pemecahan Masalah mengalami peningkatan yang lebih baik.

Adapun masalah yang dirasakan pada siklus pertama siswa mengalami masalah dalam pembelajaran, karena pada tahap ini siswa masih beradaptasi terhadap pendekatan pembelajaran juga kemampuan matematika yang diberikan tetapi pada siklus berikutnya sudah mulai menyesuaikan terhadap pendekatan pembelajaran dan lebih fokus terhadap kemampuan pemecahan masalah matematik sehingga kegiatan belajar mengajar lebih bermakna. Kebermakanaan dalam kemampuan Pemecahan Masalah matematika sangat penting agar pemikiran dasar siswa menjadi paham atas 
masalah yang akan dicari penyelsaianya. Dalam mengembangkan keterampilan kemampuan Pemecahan Masalah matematika tidak hanya memahami konsepnya saja atau prosedurnya saja, akan tetapi banyak hal yang dapat muncul dari hasil proses pembelajaran matematika. Kebermaknaan dalam belajar matematika ditandai dengan kesadaran apa yang dilakukan, apa yang dipahami dan apa yang tidak dipahami oleh peserta didik tentang fakta, konsep, relasi, dan prosedur matematika. Menurut Afgani (Siti Mawaddah, 2015) kebermaknaan dalam belajar matematika akan muncul manakala aktivitas yang dikembangkan dalam belajar matematika memuat standar proses pembelajaran matematika, salah satunya kemampuan Pemecahan Masalah matematika.

Seorang siswa akan bisa memecahkan masalah kemampuan Pemecahan Masalah matematika dalam pembelajaran tatkala siswa memahami apa yang disampaikan oleh seorang guru, konsep apa yang diberikan oleh guru, pengetahuan apa yang diberikan oleh guru, dan konsep cara proses berpikir seperti apa yang diberikan oleh seorang guru. Karena siswa akan bisa menyelesaikan soal kemampuan matematik atas dasar siswa mempelajari lebih terperinci dasar atau hubungan dalam kemampuan tersebut. Sebagaimana yang diungkapkan oleh Weitheimer (Siti Mawaddah, 2015) mengemukakan bahwa proses belajar dapat terjadi karena ditemukannya berbagai cara solusi penyelesaian dari suatu masalah. Cara penyelesaian masalah yang didapat oleh siswa merupakan hasil dari pengetahuan dan pengalaman yang dimiliki siswa terkait dengan masalah yang ingin dicari penyelesaiannya. Oleh karena itu guru harus mampu membantu siswa dalam memaknai pembelajaran matematika serta membangun kemampuan Pemecahan Masalah matematis siswa untuk memperdalam pemahaman siswa terhadap matematika.

Kesulitan yang dialami siswa pada siklus kesatu siswa mengalami kesulitan pada indikator mebuat gambar dari situasi masalah dan membuat model matematika dari suatu masalah, sedangakan Pemecahan masalah adalah suatu usaha mencapai jalan keluar dari suatu tujuan yang tidak begitu mudah segera dapat dicapai (Polya dalam Hendriana, Rohaeti, Soemarmo, 2017). Pemecahan masalah sebagai proses dimana individu menggunakan pengetahuan, keterampilan, dan pemahaman yang telah diperoleh untuk menyelesaikan masalah pada situasi yang belum dikenalnya (Krulik dan Rudnik dalam Wassahua, 2010). Namun kesulitan kesulitan siswa pada siklus satu dan siklus tiga mengalami peningkatan karena dibalik itu semua dibantu dengan pendekatan Reciprocal Teaching untuk mengatasinya.

\section{KESIMPULAN}

Berdasarkan hasil pengolahan data dan temuan yang diperoleh dari penelitian ini, maka dapat disimpulkan bahwa Rata rata nilai presentasi siswa dari siklus satu hingga siklus tiga untuk meningkatkan indikator kemampuan Pemecahan Masalah matematika dengan menggunakan pendekatan pembelajaran Reciprocal Teaching tiap siklusnya mengalami peningkatan yang lebih baik. Untuk kesulitan siswa dalam tes setiap siklus mengalami kesulitan pada indikator kemampuan Pemecahan Masalah matematik terutama dalam membuat model matematika dari suatu masalah 
yang disajikan serta kesulitan dalam membuat segmen garis yang menunjukan panjang antara dua garis . Kinerja siswa untuk setiap siklus mengalami adaptasi secara bertahap perubahan semakin baik hingga pembelajaran pada siklus tiga. Nilai rata rata akhir pada siklus tiga memiliki perubahan diatas nilai KKM Madrasah yang telah ditetapkan sehingga penelitian tindakan kelas dapat disimpulkan berhasil.

\section{DAFTAR PUSTAKA}

Akbar, P., Hamid, A., Bernard, M., \& Sugandi, A. I. (2018). Analisis kemampuan pemecahan masalah dan disposisi matematik siswa kelas xi sma putra juang dalam materi peluang. Jurnal Cendekia: Jurnal Pendidikan Matematika, 2(1), 144-153.

Aminah, S., Wijaya, T. T., \& Yuspriyati, D. (2018). Analisis Kemampuan Komunikasi Matematis Siswa Kelas Viii Pada Materi Himpunan. Jurnal Cendekia: Jurnal Pendidikan Matematika, 2(1), 15-22. https://doi.org/10.31004/cendekia.v2i1.29

Bernard, M., \& Setiawan, W. (2020). Development of Geometry Analysis Using Geogebra Scripting in terms of Student Cognitive Capabilities. In Journal of Physics: Conference Series (Vol. 1521, p. 032103).

Bernard, M., Novtiar, C., \& Rohaeti, E. E. (2020). Penerapan Permainan Operasi Bilangan Bulat Menggunakan VBA pada Guru Kecamatan Pangalengan. ETHOS: Jurnal Penelitian dan Pengabdian kepada Masyarakat, 8(1), 49-58.

Bernard, M., \& Sunaryo, A. (2020). Analisis Motivasi Belajar Siswa MTs dalam Pembelajaran Matematika Materi Segitiga dengan Berbantuan Media Javascript Geogebra. Jurnal Cendekia: Jurnal Pendidikan Matematika, 4(1), 134-143.

Dewi, S. N., Wijaya, T. T., Budianti, A., \& Rohaeti, E. E. (2018). Pengaruh Model Teams Games Tournament Terhadap Kemampuan Pemahaman Matematik Siswa Kelas XI SMK di Kota Cimahi Pada Materi Fungsi Eksponen. WACANA AKADEMIKA: Majalah Ilmiah Kependidikan, 2(1), 99. https://doi.org/10.30738/wa.v2i1.2570

Hendriana dan Soemarmo. 2014. Penilaian Pembelajaran Matematika. Bandung: Pt Refika Aditama

Hendriana, Heris, Euis Eti Rohaeti Dan Utari Sumarmo. 2017. Hard Skills Dan Soft Skills Matematik Siswa. Bandung: PT. Refika Aditama.

Hutajulu, M., Wijaya, T. T., \& Hidayat, W. (2019). the Effect of Mathematical Disposition and Learning Motivation on Problem Solving: an Analysis. Infinity Journal, 8(2), 229. https://doi.org/10.22460/infinity.v8i2.p229-238

Juhaeri M . (2014 ). Peningkatan Kemampuan Berpikir Kritis, Berpikir Kreatif Matematis, Dan SelfConcept Siswa Smp Melalui Metode Reciprocal Teaching .(Tesis ). Universitas Pendidikan Indonesi (UPI). Bandung

Lin, Y., Zhou, Y., Wang, S., \& Wijaya, T. T. (2020). LESSON DESIGN OF GEOMETRIC SEQUENCES BASED ON THE 6-QUESTION COGNITIVE THEORY. Journal On Education, 02(04), 313-322.

Linda, L., Bernard, M., \& Fitriani, N. (2020). Analisis Kesulitan Siswa SMP Kelas VIII pada Materi Segiempat dan Segitiga Berdasarkan Tahapan Berpikir Van Hiele. Journal of Medives: Journal of Mathematics Education IKIP Veteran Semarang, 4(2), 233-242.

Pirmanto, Y., Anwar, M. F., \& Bernard, M. (2020). ANALISIS KESULITAN SISWA SMA DALAM 
MENYElesaikan Soal Pemecahan Masalah Pada Materi Barisan Dan Deret Dengan LangkahLangkah Menurut Polya. JPMI (Jurnal Pembelajaran Matematika Inovatif), 3(4), 371-384.

R, Ari Hestaliana (2015) meningkatkan kemampuan pemecahan masalah, komunikasi, dan selfregulation matematis melalui penerapan model pembelajaran reciprocal teaching berbasis saintifik pada siswa smp. S2 thesis, Universitas Pendidikan Indonesia.

Sari, D. R., \& Bernard, M. (2020). Analisis Kesalahan Siswa SMP dalam Menyelesaikan Soal Materi Statistika di Bandung Barat. Journal of Medives: Journal of Mathematics Education IKIP Veteran Semarang, 4(2), 223-232.

Siti Mawaddah, H. A., \& Pendidikan. (2015). Kemampuan Pemecahan Masalah Matematis Siswa Pada Pembelajaran Matematika Dengan Menggunakan Model Pembelajaran Generatif (Generative Learning) Di Smp. Edu-Mat Jurnal Pendidikan Matematika, 3, 166-175.

Sukayati. Penelitian Tindakan Kelas. Yogyakarta: Pusat Pengembangan dan Pemberdayaan Pendidik dan Tenaga Kependidikan Matematika, 2008

Suyatno. 2009. Menjelajah Pembelajaran Inofatif. Sidoarjo: Masmedia Buana Pusaka

Susila, I. (2015). Pendeketan Kualitatif Untuk Riset Pemasaran dan Pengukuran Kinerja Bisnis. BENEFIT Jurnal Manajemen Dan Bisnis, 19, 12-23.

Suan, L., Ying, Z., \& Wijaya, T. T. (2020). Using hawgent dynamic mathematics software in teaching arithmetic operation. International Journal of Education and Learning, 2(1), 25-31. https://doi.org/10.31763/ijele.v2i1.97

Trianto (2007). Model-model Pembelajaran Inovatif Berorentasi Kontruktivisti.Jakarta: Prestasi Pustaka.

Wijaya, T.T., Ying, Z., \& Purnama, A. (2020). Using Hawgent dynamic mathematics software in teaching trigonometry. International Journal of Emerging Technologies in Learning, 15(10). https://doi.org/10.3991/ijet.v15i10.13099

Wijaya, Tommy Tanu, Purnama, A., \& Tanuwijaya, H. (2020). Pengembangan Media Pembelajaran Berdasarkan Konsep Tpack pada Materi Garis dan Sudut Menggunakan Hawgent Dynamic Mathematics Software. JPMI - Jurnal Pembelajaran Matematika Inovatif, 3(3), 205-214. https://doi.org/10.22460/jpmi.v1i3.205-214

Wijaya, Tommy Tanu, Sukma, M., Purnama, A., \& Tanuwijaya, H. (2020). Pengembangan media pembelajaran berbasis tpack menggunakan hawgent dynamic mathematics software. Journal of Elementary Education, 03(03), 64-72.

Wijaya, Tommy Tanu, Ying, Z., Chotimah, S., \& Bernard, M. (2020). Hawgent dynamic mathematic software as mathematics learning media for teaching quadratic functions Hawgent dynamic mathematic software as mathematics learning media for teaching quadratic functions. https://doi.org/10.1088/1742-6596/1592/1/012079

Wiliawanto, W., Bernard, M., Akbar, P., \& Sugandi, A. I. (2019). Penerapan Strategi Pembelajaran Aktif Question Student Have Untuk Meningkatkan Kemampuan Berpikir Kritis Matematik Siswa SMK. Jurnal Cendekia: Jurnal Pendidikan Matematika, 3(1), 139-148.

Zulfah, Astuti, Surya, Y. F., Marta, R., \& Wijaya, T. T. (2020). Measurement of mathematics problems solving ability using problem based mathematics question Measurement of mathematics problems solving ability using problem based mathematics question. Journal of Physics: Conference Series, 1613(1). https://doi.org/10.1088/1742-6596/1613/1/012026 